\title{
The authority to order search in a comparative perspective: a call for judicial oversight ${ }^{1}$
}

\section{A autoridade competente para determinar buscas e apreensões em perspectiva comparada: pela necessidade de controle judicial}

\author{
Karolina Kremens ${ }^{2}$ \\ University of Wroclaw, Poland \\ karolina.kremens@uwr.edu.pl \\ http://orcid.org/0000-0002-2132-2645
}

\begin{abstract}
AвSTRACt: Searches are an example of investigative actions aimed at the discovery of evidence, and failures in conducting them lawfully and reasonably have a direct impact on the admissibility of evidence during a trial. But searches by their nature also significantly interfere with the rights of the individual, which makes them a coercive tool that can very easily deprive a person of their privacy and dignity. For that reason, provisions concerning search must be shaped in a way that will reconcile the effectiveness of the investigation with adequate protection against unlawful searches. One such safeguard is the question of the authority empowered to order searches that will successfully safeguard the rights of the individual. While it is a rule in some countries (e.g. USA and Germany) that the issuing of search warrants remains exclusively in the hands of the judge, some countries (e.g. Poland and Italy) vest that power in the hands of the prosecutor. However, since the majority of searches are conducted without a warrant, it is necessary
\end{abstract}

1 This work is a result of the research project financed by the Polish National Science Center 2018/30/E/HS5/00338. The earlier version of this article has been presented during the $8^{\text {th }}$ Annual Conference of the Younger Comparativists Conference of the ASCL held at the McGill Law School on May 10, 2019. I am grateful to all participants for their helpful comments.

2 PhD in Law from the University of Wrocław (Poland) and LL.M. from the University of Ottawa (Canada). Assistant Professor at the Department of Criminal Procedure at the Faculty of Law, Administration and Economics (University of Wrocław, Poland). 
to analyze in parallel whether the warrantless searches should be left solely to the discretion of the executing authority or whether they should be placed under the more careful scrutiny of another authority. This will be done with the aim of identifying solutions that provide the best protection for a person against unreasonable and disproportionate searches.

KEYWORDS: search; search warrant; criminal investigation; prosecutor; prosecutorial powers.

Resumo: Buscas e apreensões são exemplos de meios de investigação dirigidos à descoberta de elementos probatórios, e irregularidades na sua condução de modo legal e razoável acarretam impacto direto na admissibilidade da prova durante o juízo. Contudo, buscas e apreensões por sua natureza também refletem significativamente em intervenções nos direitos individuais, caracterizando tais medidas como coercitivas e com risco de violações à privacidade e à dignidade da pessoa. Por esse motivo, a regulamentação das buscas e apreensões deve se dar de um modo compatível com a necessidade de efetividade das investigações e com uma proteção adequada contra atos abusivos. Uma dessas garantias é determinada pela definição da autoridade competente para ordenar as buscas e apreensões e a sua capacidade de proteger os direitos individuais. Enquanto é uma regra em alguns países (ex. EUA e Alemanha) que a expedição de um mandado de busca e apreensão somente pode ser determinada pelo juízo, em outros (ex. Polônia e Itália) isso pode ser feito pelo Ministério Público. Entretanto, como a maioria das buscas e apreensões são realizadas sem mandado, é necessário analisar em paralelo se medidas sem mandado deveriam ser relegadas à discricionariedade da autoridade executante ou se deveriam ser submetidas a rigoroso controle por outra autoridade. Isso será feito com o objetivo de identificar soluções para assegurar a melhor proteção à pessoa contra buscas e apreensões abusivas e desproporcionais.

Palavras-chave: busca e apreensão; mandado; investigação criminal; Ministério Público; poderes da promotoria.

\section{INTRODUCTION}

Significant importance must be attached to search as an example of investigative action aimed at the discovery of evidence. Failures in 
conducting lawful and reasonable searches have a direct impact on the admissibility of evidence during a trial. Nonetheless, searches in their nature significantly interfere with the rights of the individual, such as the right to privacy, personal inviolability, and inviolability of the home. For that reason, legal provisions concerning search must be shaped in a way that reconciles the effectiveness of the investigation with adequate protection against unreasonable searches and unlawful interference with the individual's rights and freedoms. One such safeguard is the question of the authority empowered to order searches that will successfully safeguard the rights of the individual.

Therefore, the goal of this work is to establish which authority within the criminal justice system shall retain control over searches. The foremost question is which authority should be qualified to issue search warrants and what should be the minimal features of such authority. Even though practice shows that the rule understood as prior authorization to conduct a search has become an exception, it is still important as it gives the most protection to an individual. Only prior evaluation of the necessity of conducting a search may give full, comprehensive, and desirable protection against unreasonable infringements of rights. If the search has already taken place, even the most effective remedy can only be considered cosmetic treatment for what has been done. But making a prior decision to conduct a search raises some additional concerns, such as whether the results of such a decision shall remain unverified until the evidence obtained during the search is introduced at trial, or whether it should be subject to some form of control. And if so, who should undertake it, and when.

However, taking into account that the majority of searches are conducted without a warrant due to a certain number of exceptions, it is necessary to analyze in parallel whether these warrantless searches should be left solely to the discretion of the executing authority or whether they should remain under the more careful scrutiny of another authority. Therefore, the issue of grounds that allow police officers to conduct a search without a warrant under exigent circumstances will be discussed accordingly. Furthermore, the analysis will focus on which authority, if any, is capable of controlling such not preauthorized searches. It seems problematic to leave warrantless searches without any further control 
unless evidence obtained during such a search is introduced during a subsequent trial. Should the legality of such search only be a theme for discussion when the evidence is to be produced during trial? Or should the individual whose rights were infringed by the unlawful search be entitled to immediate and effective remedy even when the case is dismissed or disposed without a trial?

The discussion leading to the determination of the authority eligible to decide whether to allow a search or not will be done through comparative research. This will allow the consideration of different perspectives and different resolutions to the same problem that authorities in all countries encounter while investigating crimes. The choice of countries for the comparative research was made with the aim of showing a variety of approaches to criminal procedure in general. Therefore, the United States will be used as a good example of a common law system with very well-developed case law in particular regarding search. In fact, the US will be used as a starting point for the further analysis, since the country has a long-standing perspective on what kind of authority shall be responsible for making the decision to search a person, an object, or a premises.

On the other side of this discussion shall be Continental European countries easily identified through the strong involvement of the prosecutor in the course of the criminal investigation. While in the US the prosecutor most commonly only becomes engaged in a criminal process when the decision to charge a person with a crime must be made, in countries that use the Continental system the prosecutor is a central figure of the criminal investigation. This is equally true for Germany, Italy, and Poland, chosen as examples on the Continental side. Therefore, it must also be taken into consideration whether the role of the prosecutor during a criminal investigation may be a factor or even a deciding element in assigning such competences as ordering a search to the prosecutor. Hence, another question that shall be asked is whether the role that the prosecutor plays during an investigation influences the decision to whom the competence to order a search should be assigned.

The choice of Germany is dictated by the fact that this country is often seen as the mother of Continental law. In contrast, Italy is an interesting example of a country that, being traditionally associated 
with an inquisitorial system, has shifted towards the adversarial model through an almost epic change of the Code of Criminal Procedure in $1988^{3}$. Therefore, it seems interesting to see how this new approach has changed the Italian model of criminal investigation and whether the position of the actors at this stage of a criminal process, in particular with regard to the authority to order a search, resembles the American example to which Italy has been aspiring. Finally, Poland has been chosen as a country not commonly considered in legal comparative analyses. Poland however is also a country that for many years found itself under the Soviet regime, which has inevitably had a lasting impact on Polish criminal procedures. Therefore, it may be seen as representative of a group of countries belonging to the old Eastern Block.

First, a descriptive analysis of normative regulations as adopted in each country will be provided. This will be done in the form of separate reports for each chosen country (US, Italy, Poland and Germany) according to the adopted method of comparative research ${ }^{4}$. Each subchapter will discuss the procedure for issuing a search warrant with a focus on the authority entitled to make such decisions as well as options to challenge the conducted preauthorized search, if applicable. Then, the discussion will move in the case of each country to guarantees provided to the individual when it comes to warrantless searches. In particular, the necessity to obtain post-approvals by officers that executed the search as well as remedies available to the individual in the case of an infringement of their rights will be analyzed.

This comparative analysis aims to lay a foundation for further comparative analysis with the aim of identifying those resolutions

3 On the Italian reform of the criminal process see for example AMODIO, Ennio; SELVAGGI, Eugenio. An Accusatorial System in a Civil Law Country: The 1988 Italian Code of Criminal Procedure. Temple Law Review, n. 62, 1989, p. 1211; ILLUMINATI, Giulio. The Frustrated Turn to Adversarial Procedure in Italy (Italian Criminal Procedure Code of 1988). Washington University Global Studies Law Review, n. 4, 2005, p. 567; PANZAVOLTA, Michele. Reforms and Counter-Reforms in the Italian Struggle for an Accusatorial Criminal Law System. North Carolina Journal of International Law \& Commercial Regulation, n. 30, 2004, p. 577.

4 ZWEIGERT, Konrad; KÖTZ, Hein. Introduction to Comparative Law. Oxford: Clarendon Press, 2011, p. 43. 
that provide the best protection for a person against unreasonable and disproportionate searches. The discussed systems are accordingly compared. Moreover, two issues will be brought up to make an argument that the only plausible choice for the authority that shall have the competence to control searches is the independent and impartial judge, both in cases of preauthorized searches and those executed in the absence of search warrants. This will be done in the light of the position that the prosecution service has in each country, being associated either with the executive or the judiciary. Additionally, it will also be taken into account that the level of engagement of the prosecutor during a criminal investigation and the relationship between the prosecution and police are important factors in shaping the optimal model of a system that aims to guarantee efficient protection for the individual against unreasonable searches.

\section{REPORTS ON REgULATIONS REGARDING SEARCH IN CHOSEN COUNTRIES}

\section{Search in the United States of America}

\subsection{General considerations}

Search in the USA is primarily regulated by the Fourth Amendment, which guarantees protection against unreasonable search and seizure of persons, places, and objects. Several issues are resolved by this regulation. First of all, the Fourth Amendment demonstrates a "strong preference for searches conducted pursuant to warrant" . Even though warrantless searches are a daily routine for police officers throughout all US states, the prior judicial oversight of a coercive measure such as a search is considered a rule and not an exception ${ }^{6}$.

Secondly, the key feature of constitutional regulation is the connection that it creates between search (and seizure) and probable cause,

5 Illinois v. Gates, 462 U.S. 213 (1983) 236.

6 But see a critical observance of that in GRAY, David. Fourth Amendment Remedies as Rights: The Warrant Requirement. Boston University Law Review, 2016, n. 96, pp. 433-436. 
making the latter a threshold that must be met if any coercive measure is to be imposed against an individual. What is understood by that term seems unclear and problematic. In Carroll v. United States it was stated that probable cause exists where "the facts and circumstances within [the arresting officers'] knowledge and of which they had reasonably trustworthy information [are] sufficient in themselves to warrant a man of reasonable caution in the belief that [an offense has been or is being committed]"7. There is an obvious lack of agreement on the meaning of probable cause and on the level of certainty that should be reached in each case when a decision to search or seize is employed ${ }^{8}$. However, in federal law and in the majority of states it is adopted that what matters in determination of probable case is the "totality of circumstances".

Finally, since the landmark decision in Katz $v$. United States, the Fourth Amendment has been interpreted as protecting persons whenever they have "reasonable expectation of privacy" ${ }^{10}$, overruling previous interpretation of the constitutional rule that provided for protection of places but not persons ${ }^{11}$. This covers all kind of searches (persons, objects, and places) by the Fourth Amendment requirements. Accordingly, it is also crucial to understand the difference that exists between search and the other unaffected form of interference with the privacy of a person, called stop and frisk. In concise terms, a police officer may stop a suspect on the street and frisk him if the police officer has just a reasonable suspicion. This requires a lower level of certainty than probable cause to believe that the person has committed, is committing, or is about to commit a crime or a reasonable belief that the person "may be armed and presently dangerous"12. And only if stop and frisk gives rise to probable cause to believe that the suspect has committed

7267 U.S. 132 (1925) 162. See also Brinegar v. United States, 338 U.S. 160 (1949).

8 Cf. COLB, Sherry F. Probabilities in Probable Cause and Beyond: Statistical Versus Concrete Harms. Law and Contemporary Problems, n. 73, pp. 69-105, 2010, p. 69.

$9 \quad$ Illinois v. Gates, 462 U.S. 213 (1983) 214.

10 Katz v. United States, 389 U.S. 347 (1967) 361.

11 See Olmstead v. United States, 277 U.S. 438 (1928).

12 Terry v. Ohio, 392 U.S. 1 (1968) 27. 
a crime should the police be empowered to make a formal arrest and a full incident search of the person ${ }^{13}$.

\subsection{SEARCH UPON A WARRANT}

The obligation to obtain a search warrant before executing a search, derived directly from the wording of the Fourth Amendment, is a rule both on federal and - since Mapp $v$. Ohio ${ }^{14}$ - on state level. The search warrant is issued upon the request of a police officer filed with a judge or magistrate in the form of an affidavit in which the applicant officially confirms facts as provided in the document and which contains detailed information regarding who or what should be searched and what in effect should be seized ${ }^{15}$. Each affidavit as a basis for issuing a search warrant is considered to be reliable because it contains information given by the officer under oath ${ }^{16}$. Therefore, the majority of searches with a warrant happen upon the request of police officers or other agents since they are primarily responsible for conducting the criminal investigation, with almost no involvement of prosecutors in the early stages of criminal proceedings. But the law also allows prosecutors to file requests with the judge if they deem it necessary. This usually happens when the prosecutor takes control of a criminal investigation after charges are filed with the court.

The responsibility of issuing search warrants rests ultimately with a judicial authority, i.e. a judge or magistrate. This is based on a premise that an impartial magistrate should be interposed between the citizen and the law enforcement agents whose job is the detection of crime "so that an objective mind might weigh the need to invade that privacy in order to enforce law"17. According to US standards it is required

13 Terry v. Ohio, 392 U.S. 1 (1968) 10.

14367 U.S. 643 (1961).

15 SCHEB, John M; SCHEB, John M II. Criminal Procedure. Belmont: Wadsworth, 1999, p. 50.

16 See DRESSLER, Joshua; THOMAS III, George. Criminal Procedure. Principles, Policies and Perspectives. St Paul: West Academic, 2017, p. 201.

17 McDonald v. United States, 335 U.S. 451 (1948) 455. 
that the individual issuing a search warrant must not be in close relation with the criminal investigation authorities that will execute the order, so as to be able to evaluate from a distance and without pressure their requests ${ }^{18}$. This seems to be an approach broadly adopted throughout the US states.

After the search warrant has been issued there is no subsequent judicial scrutiny over the search unless the evidence seized during the search is to be used during a trial when it is done in the form of a motion to suppress evidence in accordance with the exclusionary rule ${ }^{19}$. If the case does not reach the trial stage the system remains uninterested in the outcome of the search conducted upon the warrant other than the obligation of the officer to return the warrant if it was not executed within the prescribed term (usually 14 days) ${ }^{20}$. Only if the search resulted in the seizure of property or if the search was unlawful, may move to the court for the return of property ${ }^{21}$. This means that the system does not provide within the criminal process any remedy if the rights of an individual were infringed by an unlawful search upon a warrant that did not result in the suppression of evidence.

\subsection{WARRANTLESS SEARCH}

It is well understood in US law that "searches conducted outside the judicial process, without prior approval by judge or magistrate, are per se unreasonable under the Fourth Amendment - subject only to a few specifically established and well delineated exceptions" ${ }^{22}$. This is usually called the "warrant requirement" that gives a strong preference for search

18 Johnson v. United States 333 U.S. 10 (1948).

19 See on exclusionary rule Boyd v. United States, 116 U.S. 616 (1886), Weeks v. United States, 232 U.S. 383 (1914), Wolf v. Colorado, 338 U.S. 25 (1949), Rochin v. California, 342 U.S. 165 (1952) and Mapp v. Ohio, 467 U.S. 643 (1961).

20 See on the federal level Rule 41 (f)(1)(D) Federal Rules of Criminal Procedure.

21 See on the federal level Rule 41 (g) Federal Rules of Criminal Procedure.

22 Katz v. United States, 389 U.S. 347 (1967) 357. 
upon a warrant over searches without a warrant ${ }^{23}$. But, as was aptly observed by Judge Scalia concurring in California v. Acevedo, "the "warrant requirement' had become so riddled with exceptions that it was basically unrecognizable" ${ }^{24}$.

One such exception is exigent circumstances that arise from the need to conduct some searches in a dynamic manner. As it was held by the Supreme Court, "where there are exigent circumstances in which police action literally must be 'now or never' to preserve the evidence of the crime, it is reasonable to permit action without prior judicial authorization" ${ }^{25}$. Such exigent circumstances normally arise in cases involving automobile searches justified by the possible loss of evidence due to the mobility of the vehicle ${ }^{26}$ and during the well-developed practice of searches incident to arrest ${ }^{27}$. Moreover, searches conducted upon the consent of the searched individual are also considered an exception to the warrant requirement ${ }^{28}$. This all leads to the situation where the police retain considerably wide discretion to decide who will be searched and whose house will be entered, and where warrantless search created as an exception has become a rule.

It is true that in every case in which police officers conduct a search without a warrant claiming that exigent circumstances arose, they must provide evidence that they didn't have time to apply for the search warrant due to a suspicion that evidence may be hidden or destroyed ${ }^{29}$. But this will happen only when the prosecutor intends to introduce at trial the evidence obtained during such a search. If the case is disposed before the trial or dismissed there is no instrument in US law that allows for checking

23 Dyson v. State, 122 Md.App. 413, 712 A.2d 573 (1998) ("the command of the Fourth Amendment to the American police officer and the American Prosecutor is simple: 'You always have to get a warrant - UNLESS YOU CAN'T'”).

California v. Acevedo, 500 U.S. 565 (1991) 583.

Roaden v. Kentucky, 413 U.S. 496 (1973) 505.

Carroll v. United States, 267 U.S. 132 (1925).

See Chimel v. California, 395 U.S. 752 (1969) and United States v. Robinson, 414 U.S. 218 (1973) and Riley v. California, 573 U.S. _ (2014). See also DRESSLER, Joshua; THOMAS III, George, op. cit., pp. 251-275. Schneckloth v. Bustamonte, 412 U.S. 218 (1973).

Schmerber v. California, 384 U.S. 757 (1966). 
the grounds for the search and the nature of the conducting of this measure. There is no confirmation of a warrantless search by any entity and there is no form of interlocutory appeal against an unreasonable search.

Therefore, within the scope of criminal process the only effective remedy in cases of unlawful searches is an exclusionary rule. Theoretically, there are some other remedies available to the individual whose rights were infringed by the unlawful search, but they remain outside of the scope of criminal process. The affected individual may resort to civil procedure and sue the police officer who performed an unreasonable search. However, due to the doctrine of qualified immunity protecting government employees when they perform certain actions pertinent to their occupations, this is very unlikely to happen, since an officer may only be sued when no reasonable person would believe that the officer's conduct was legal ${ }^{30}$. Another option is prosecution of an officer for illegal search and seizure, which also remains outside of the criminal proceedings in the case in which the illegal action occurred. All these remedies are reported as being rare and therefore cannot be considered as effective tools to fight the outcome of illegal searches.

\section{SeARCh in Italy}

\subsection{General considerations}

Protection of the individual against the search and seizure of a person (arrest) is regulated jointly in the Constitution of the Italian Republic $^{31}$ as a form of interference with personal freedom (Article 13 of the Italian Constitution). In parallel to this regulation, search of a home and other premises is protected on the constitutional level as a form of

30 See Graham v. Connor, 490 U.S. 386 (1989) 396 ("The 'reasonableness' of a particular use of force must be judged from the perspective of a reasonable officer on the scene"). See also Justice Ginsburg's concurrence in Saucier v. Katz, 533 U.S. 194 (2001) 214 ("an officer whose conduct is objectively unreasonable under Graham should find no shelter under a sequential qualified immunity test”).

31 La Costituzione della Repubblica Italiana of 27 December 1947 [hereinafter Italian Constitution]. 
interference with privacy (Article 14 of the Italian Constitution). The guarantees prescribed for safeguarding personal freedom (e.g. regarding the authority responsible for issuing search orders) are applicable to other forms of interference with privacy according to Article 14 (2) of the Italian Constitution. Further provisions provide for the protection of the secrecy of correspondence (Article 15 of the Italian Constitution).

Accordingly, the Italian Code of Criminal Procedure ${ }^{32}$ provides for the search of a person (perquisizione personale - Article 249 (1) CCP-Italy), search of premises (perquisizione locale - Article $250 \mathrm{CCP}$ ), and, introduced in 2008, search of computers and electronic systems (perquisizione informatica - Article 247 (1bis) CCP-Italy) ${ }^{33}$. All searches may only be conducted if there are reasonable grounds to believe (fondato motive di ritenere) that objects used to commit an offence or related to an offence are possessed by the person who is to be searched or are located in a place that is to be searched as well as that the accused who must be arrested remains in such place (Article 247 (1) CCP-Italy). This vague prerequisite (i.e. "reasonable grounds") allows for a search to be conducted if it is reasonable to predict that a search will be fruitful, and even if at the end of the search it turns out that this suspicion was groundless (no objects were found) it does not necessarily undermine the legality of the search ${ }^{34}$.

\subsection{Searches upon a warRant}

Neither the constitution nor the CCP-Italy directly demands that the judge (court) issues search warrants. Instead Article 13 of the Italian

32 Codice di Procedura Penale, Decreto del presidente della Repubblica, 22 September 1988, no. 447 [hereinafter CCP-Italy].

33 The law also provides for inspections (ispezioni) aimed at ascertaining the traces or other effects of the crime on persons, places, and objects, including computer and telecommunication systems (see on that difference LASAGNI, Giulia. Tackling phone searches in Italy and the United States: Proposals for a technological rethinking of procedural rights and freedoms. New Journal of European Criminal Law, n. 9, pp. 386-401, 2018, p. 393, footnote 27).

34 CAIANIELLO, Michele. Increasing Discretionary Prosecutor's Powers: The Pivotal Role of the Italian Prosecutor in the Pretrial Investigation Phase. Oxford: Oxford Handbooks Online, 2016, p. 6. 
Constitution pronounces that the decision to impose measures infringing rights of individuals is vested in the hands of the authority prescribed more broadly as "judicial authority" (l'autorità giudiciaria). However, the constitution does not explain what is understood by this term, leaving this for further interpretation. Similarly, Article 247 (3) CCP-Italy provides vaguely that the "judicial authority" shall be competent to conduct a search or to order police to conduct it. The established understanding in Italian constitutional law is that the term "judicial authority" refers equally to the judge and the prosecutor ${ }^{35}$. But this expression has been interpreted differently in the CCP-Italy, with alternative reference to a judge or to the prosecutor $^{36}$. In the case of searches it has been understood that during a criminal investigation the responsibility for issuing a warrant remains in the hands of the prosecutors ${ }^{37}$.

This might be somewhat surprising since the Italian criminal procedure, heavily reformed in 1988 in a direction leaning towards the adversarial system of criminal procedure, managed to establish the judge for the preliminary investigation (GIP - giudice per le indagini preliminari) with the aim of controlling the work of the public prosecutor and guaranteeing the rights of the person being investigated (Article 328 CCP-Italy). The GIP, being equipped with competences relating to restriction of personal freedom if this proves necessary during the investigation and ordering interception, is at the same time not eligible to intervene with decisions to conduct a search. This is regardless of the fact that the search as presented above on the constitutional level is clearly seen as a form of deprivation of rights of an individual.

The prosecutorial search order must always contain reasons for such a decision (Article 247 (2) CCP-Italy). This becomes a basis for subsequent judicial review of such an order, since the prosecutorial search warrant may be subjected to the interlocutory appeal received and decided by the judge. This is, however, only true for such searches

35 CAIANIELLO, Michele. Increasing Discretionary Prosecutor's Powers..., op. cit., p. 4.

36 LASAGNI, Giulia, op. cit., p. 395.

37 PERRODET, Antoinette. The Italian System. En: DELMAS-MARTY, Mireille; SPENCER, John R (eds.). European Criminal Procedures. Cambridge: Cambridge University Press, 2002, p. 377. 
that resulted in seizure of property. The accused, the person from whom objects have been seized, and the person who would be entitled to their restitution may submit a request for re-examination of the seizure, which includes the grounds for search and seizure (Article 257 (1) CCP-Italy) in accordance with the "re-examination" procedure as designed for pretrial measures (Article 324 CCP-Italy) ${ }^{38}$. This means that searches ordered by the prosecutor that resulted with no seizure simply cannot be appealed and reviewed by the judge (court). Nevertheless, it is reported that even in cases when during the search some objects were seized, the criteria provided by law are so vague that it is very complicated for the defense to show at the appeal stage that the warrant was invalid or ill founded ${ }^{39}$.

\subsection{WARRANTLESS SEARCHES}

The rule that the search should be conducted upon the prosecutorial order is overshadowed in practice by the police conducting searches without an order. The police may search a person's body or premises in each case where there are exigent circumstances and when they have reasonable grounds to believe that the person is hiding objects or traces related to the offence on his body that can be lost or destroyed or that such objects or traces are in a certain place or that the suspected person or the escapee is in such a place (Article 352 (1) $\mathrm{CCP})^{40}$. The exigent circumstances are understood as an urgent situation that happens in the case of a flagrant crime or in the case of an escape. In every case a warrantless search undertaken by the police is subject to confirmation by the prosecutor ${ }^{41}$. The police have only 48 hours to inform a prosecutor that such a search has been conducted and the prosecutor has an additional 48 hours to confirm it (Article 352 (4)

38 CAIANIELLO, Michele. Increasing Discretionary Prosecutor's Powers..., op. cit., p. 5.

39 CAIANIELLO, Michele. Increasing Discretionary Prosecutor's Powers..., op. cit., p. 5.

40 This also applies to searches of computer and electronic systems according to Article 352 (1bis) CCP.

41 DI AMATO, Astolfo. Criminal Law in Italy. Alphen aan den Rijn: Kluwer Law International, 2013, p. 181. 
CCP). This happens regardless of whether anything was found through such search. Moreover, in accordance with Article 257 (1) CCP-Italy, the search can be appealed, but, as was discussed above, again only in cases where a seizure took place during the search.

\section{Search in Poland}

\subsection{General considerations}

In Polish law the search (przeszukanie) is understood as a form of interference with the rights of the individual, which are guaranteed on a constitutional level ${ }^{42}$. The searching of persons, objects, and premises is primarily conflicting with a right to protection of private and family life expressed in Article 47 of the Polish Constitution ${ }^{43}$. But in many instances the search is also seen as interference with the principle of the inviolability of the home, protected under Article 50 of the Polish Constitution and a search of a person, apart from interfering with one's privacy, also intrudes on personal inviolability, protected under Article 41(1) of the Polish Constitution ${ }^{44}$. Surprisingly, though setting a high standard for the protection of the rights of the individual, the Polish Constitution remains absolutely silent when it comes to determining the authority that retains the power to order a search in all of these provisions.

The Polish Code of Criminal Procedure ${ }^{45}$ regulates searches in Chapter 25, entitled "Seizure of Things and Searches". Article 219 CCP-

42 See SKORUPKA, Jerzy. Konstytucyjne i konwencyjne granice przeszukania w postępowaniu karnym (cz. I). Palestra, v. 9-10, 2007, p. 92 and GROCHOWSKI, Jacek. Przeszukanie w procesie karnym jako instytucja wyznaczająca granice konstytucyjnych praw osobistych. Problemy Prawa Karnego n. 17, 1991, p. 126.

43 Konstytucja Rzeczpospolitej Polskiej of 2nd April 1997 (Dz. U. z 1997 r., Nr 78, poz. 483) [hereinafter: Constitution of Poland].

44 KREMENS, Karolina. The limits of interference with the right to privacy and property in criminal proceedings. En: SKORUPKA, Jerzy (ed.). The model of acceptable interference with the rights and freedoms of an individual in criminal process. Warszawa: Wolters Kluwer, 2019, p. 585.

45 Kodeks postępowania karnego, ustawa 6 June 1997 (Dz.U. 2017, poz. 1904) [hereinafter: CCP-Poland]. 
Poland does not provide a definition of search. It describes the grounds to search premises and other locations ( $§ 1$ ) as well as persons, persons' apparel, and personal effects ( $\$ 2$ ). Accordingly, scholars distinguish between the search of premises, which may include a vehicle, and that of a person, which may include a person's apparel and their belongings. However, the CCP does not limit who exactly can be searched. Therefore, a search may target a suspect but also other persons who have no formal connection with the proceedings, with no limitations to it.

In each case the search may be conducted only whenever there is "reasonable basis to believe" (uzasadnione podstawy do przypuszczenia) that a suspected person is in a place that is subjected to search (Article 219 \& 1 CCP-Poland). The same applies to the things that can be used as evidence or that must be seized (e.g. drugs). Unfortunately, case law provides no guidance on how to interpret the "reasonable basis to believe" requirement. In particular, it is unclear whether this requirement sets a standard of prima facie obviousness ${ }^{46}$. At the same time Article 219 § 1 CCP-Poland narrows down the scope of the search through its provision that the search may only be conducted if there is a need to detect or detain or ensure the compulsory appearance of a suspect or to detect objects that might serve as evidence in a case or that are subject to sequestration in criminal proceedings.

\subsection{SEARChes UPON A WARRANT}

The CCP provides for a preference of searches upon a warrant. Therefore, as a rule searches in Poland should happen primarily upon a warrant and only exigent circumstances may justify conducting a search without a warrant (Article $220 \S 3$ CCP-Poland). More precisely, it is provided that a search shall be conducted by a prosecutor herself or, upon her decision, by the police or another agency authorized to conduct criminal investigation (e.g. the Internal Security Agency or Border Security). If a search is not conducted by the prosecutor herself the officer willing to conduct the search should obtain a prosecutorial

46 KOPER, Radosław. Przeszukanie w wypadkach niecierpiących zwłoki. Prokuratura i Prawo, n. 11-12, 2014, p. 19. 
search warrant prior to the search ${ }^{47}$. The power to issue a search warrant during an investigation ultimately rests with the prosecutor (Article 220 $\S 1$ CCP-Poland). The CCP does not consider either a judge or any other authority as being competent to issue search warrants at this stage of criminal proceedings ${ }^{48}$.

Since the Polish Constitution lacks provisions prescribing the authority competent to issue search warrants and does not demand that it should be a judge, the CCP seems in compliance with the legal standard as set on the constitutional level. But the problem of whether such regulation, or rather lack of it, is sufficient has been recently discussed in Polish legal literature. As a result, scholars have called for a change to this situation, claiming that the level of engagement of the prosecutor in the course of a criminal investigation makes him too prejudiced to make an independent evaluation of the need to conduct a search ${ }^{49}$.

Such views have been expressed regardless of the mechanism available in Polish law that provides for post-factum judicial revision of prosecutorial search warrants. The person whose rights have been infringed by the issuance of a prosecutorial search warrant may file an interlocutory appeal with the court (Article 236 \& 1 CCP-Poland). In fact this provision has a much broader character, also allowing for judicial scrutiny in all cases involving seizure of things, and is available to every person whose rights have been infringed. General rules of filing an interlocutory appeal apply accordingly (Article 465 $\S 2$ CCP-Poland).

47 NOWAK, Celina; STEINBORN, Sławomir. Poland. En: LIGETI, Katalin (eds.). Toward a Prosecutor of the European Union, Volume 1: A Comparative Analysis. London: Hart Publishing, 2013, p. 519.

48 It must be noted, however, that Polish law also provides for the possibility to conduct the search during the trial stage of criminal proceedings. However, in such cases, the power to issue a search warrant rests only with the court that holds the trial (Article $220 \S 1$ CCP-Poland).

49 See STEINBORN, Sławomir. Problem organu uprawnionego do stosowania przeszukania w toku procesu karnego w świetle unormowań konstytucyjnych i prawnomiędzynarodowych. Gdańskie Studia Prawnicze, n. 19, 2008, p. 375; SKORUPKA, Jerzy. Konstytucyjne i konwencyjne granice przeszukania w postępowaniu karnym (cz. II). Palestra, n. 11-12, 2007, , p. 52. 


\subsection{WARRANTLESS SEARCHES}

Nevertheless, the obvious need to conduct searches in exigent circumstances forced lawmakers to allow the police to conduct a search without a warrant. The competence to conduct the search in the case of exigent circumstances applies not only to police but also to all other agencies that are allowed to conduct criminal investigations. This is only allowed when there is an "urgent need" to conduct a search and there is no possibility to obtain a prosecutorial search warrant (Article 220 § 3 CCP-Poland). The term "exigent circumstances" justifying warrantless searches is considered as unclear and imprecise ${ }^{50}$. Surprisingly the case law does not provide any help in this matter. But in literature it is accepted that exigent circumstances justifying warrantless search exist when commencing an investigative action with a delay due to time lost while obtaining a prosecutorial warrant or lack of action would result in the loss, distortion, or destruction of evidence ${ }^{51}$. Existence of these circumstances must be evaluated in the light of the circumstances that existed when the search was conducted and not as seen at the time when being evaluated by the judge ${ }^{52}$. Among these circumstances are the need to act immediately, the lack of possibility to obtain a warrant, but also that general grounds to conduct a search upon a warrant enlisted in Article 219 § 1 CCP-Poland took place, i.e. that the "reasonable basis to believe" requirement has been established before undertaking a search in this dynamic situation.

In cases when the search is conducted without a warrant, the police, immediately upon the conclusion of the search, must in every case apply to the prosecutor for confirmation of a conducted warrantless search (Article 220 \& 3 CCP-Poland). Issuing the confirmation is obligatory in every case and consequences of not doing so are grave. If the search is not confirmed within seven days of the day it took place, the objects seized during the search must immediately be returned to the owner (Article $230 \S 1$ CCP-Poland). In accordance with Article $236 \S 1$ CCP-Poland,

50 SAKOWICZ, Andrzej. Poszanowanie życia prywatnego w postępowaniu karnym. Jurysta, n. 6, 2000, p. 21.

51 KOPER, Radosław, op. cit., pp. 20-21 and literature cited in footnote 14.

52 SKORUPKA, Jerzy. Komentarz do art. 220 k.p.k. En: SKORUPKA, Jerzy (ed.), Kodeks postępowania karnego. Komentarz. Warszawa: CH Beck, 2018, p. 516. 
the decision confirming a warrantless search as well as the search itself is subjected to an interlocutory appeal. All general rules regarding interlocutory appeals apply.

\section{Search in Germany}

\subsection{General considerations}

Search (Durchsuchung) is a typical coercive measure yet must also be considered as an important investigative tool. Any person that is suspected of a crime may be subject to a search that can include the search of their body, property, or premises (including their home) ( $\$ 102 \mathrm{CCP}-$ Germany). The threshold for a search is quite low, i.e. the search can be conducted for the purpose of arresting the suspect, as well as in cases where it may be presumed that the search will lead to the discovery of evidence. But upon additional prerequisites the search may also be conducted against persons other than the suspect. This type of search is permissible only for the purpose of arrest of a suspect or to follow up the traces of a criminal offence or to seize certain objects, and only if certain facts support the conclusion that the person, trace, or object sought is located on the premises to be searched ( $\$ 103$ (1) CCP-Germany first sentence) $)^{53}$.

The German Constitution (Grundgesetz) ${ }^{54}$ provides for the protection of the rights of individuals that could be infringed by the search in distinct provisions. The inviolability of a person together with the right to personal integrity is provided in Article 2 (2) of the German Constitution, which also makes an assurance that such rights may be interfered with only pursuant to the law. Provisions of Article 11 of the German Constitution refer to protection of the right to privacy with regard

53 These restrictions do not apply to multiple rooms in a building in cases of a number of serious crimes against national security and terrorism, as long as there is well-founded reason to believe that the suspect is hiding somewhere in the building ( $\$ 103$ (1) CCP-Germany second sentence), or if the room is one in which the suspect either was apprehended or which he entered while being pursued ( $\$ 103$ (2) CCP-Germany).

54 Grundgesetz of 23 May 1949 (I BGBl 1949, 1) [hereinafter: German Constitution]. 
to correspondence, post, and telecommunications. Finally, the right to privacy of an individual within his premises is protected by Article 13 (1) of the German Constitution, which provides for the inviolability of the home. This right is furthermore protected by the provision of Article 13 (2) of the German Constitution that vests the right to order the search in the hands of the judge and only in exigent circumstances can the search be ordered by another authority designated by law. Following subsections of the same article (sec. 3-7) adopt an even higher standard for protection of privacy in cases of the use of secret surveillance.

\subsection{SEARCh UPON A WARRANT}

Taking into account the clear and straightforward considerations of the German Constitution, the CCP-Germany provides that searches may be ordered only by a judge ( $\$ 105$ (1) CCP-Germany). This function will be served during a criminal investigation by a special figure called "judge of the investigation" (Ermittlungsrichter). This person does not hold the position of an investigative judge as known from the French system and is not a proactive investigatory official but takes action only upon the request of the prosecutor. Such requests are made in situations when specific investigative acts are to be performed, e.g. the interrogation of witnesses or suspects ( $\$ 162$ (1) CCP-Germany) ${ }^{55}$.

This is a result of a general assumption that only a judge can impose a measure that interferes with the rights and liberties of an individual ${ }^{56}$. However the study shows that judicial scrutiny over searches does not prevent unnecessary searches since search warrants are easily granted when compared to arrest warrants ${ }^{57}$.

55 WEIGEND, Thomas. Germany. En: Ligeti K (ed.). Toward a Prosecutor of the European Union, Volume 1: A Comparative Analysis. London: Hart Publishing, 2013, p. 267.

56 WEIGEND, Thomas; SALDITT, Franz. The Investigative Stage of the Criminal Process in Germany. En: CAPE, Ed; HODGSON, Jacqueline; PRAKKEN, Ties; SPRONKEN, Taru (eds.). Suspects in Europe. Antwerpen: Intersentia, 2007, p. 85.

57 TRENDAFILOVA, Ekaterina; RÓTH, Werner. Report on the Public Prosecution Service in Germany. En: Promoting Prosecutorial Accountability, Independence 
In any case an individual affected by the search may file an interlocutory appeal with a court (Beschwerde) according to general rules that provide for the right to double check decisions made during preliminary investigation as well as during later stages of criminal proceedings ( $\$ 304$ (1) CCP-Germany). This remedy is available to all affected by the search and not only to the suspect ( $\$ 304$ (2) CCPGermany). Therefore, German law provides not only for prior judicial scrutiny of the decision to search but, upon the request of an individual, gives an opportunity for later consideration of the grounds of a search.

\subsection{WARRANTLESS SEARCHES}

Even though the law provides for the preference of searches upon a warrant preauthorized by a judge, it is reported that in the great majority of cases in which exigent circumstances exist, the search may happen without a warrant ${ }^{58}$. The "other authority", as prescribed by the German Constitution, capable of ordering a search in exigent circumstances is primarily the prosecutor ( $\$ 105$ (1) CCP-Germany). But the same power is also further extended to a big group of police officers acting on behalf of the prosecutor ${ }^{59}$. This group of so-called investigative officers or auxiliary prosecutors (Ermittlungspersonen) functions according to Article 152 (1) of the Court Organization Act (Gerichtsverfassungsgesetz) and is obliged to carry out prosecutorial orders. It generally has the same powers as the prosecutors in carrying out investigations, including the power to order a search in cases of exigent circumstances even regarding a person other than the suspect (§ 105 (1) CCP-Germany first sentence) ${ }^{60}$. The only

and Effectiveness. Sofia: Open Society Institute Sofia, 2008, p. 234.

58 KUHNE, Heinz-Heinrich. Germany. En: VAN DEN WYNGAERT, Christine (ed.). Criminal Procedure Systems in the European Community. London: Butterworths, 1993, p. 151 ("[...] a search warrant issued by a judge has become in fact rather exceptional whereas the practice of police and prosecutor searching on their own has become the rule").

59 FRASE, Richard; WEIGEND, Thomas. German Criminal Justice as a Guide to American Law Reform. Boston College International and Comparative Law Review, n. 18, 1995, p. 323.

60 Ibidem., p. 323. 
exception is searches conducted for the purpose of arresting a person strongly suspected of certain grave crimes (§ 89a, § 129a and § 129b StGB), e.g. forming national and international terrorist organizations. In these cases a search of private and other premises conducted in a building in which it may be assumed that the suspect is located may be in exigent circumstances ordered only by the prosecutor ( $\$ 105$ (1) CCP-Germany second sentence).

In German literature exigent circumstances (Gefahr im Verzug) are interpreted in a narrow way and are understood as a situation in which the search would become futile if the police officer would have to involve the prosecutor, who would then in turn have to apply to a judge for a search warrant. But in practice searches are reported to be frequently conducted without a judicial order also due to the fact that Gefahr im Verzug has been interpreted quite broadly ${ }^{61}$. Recently, however, a tendency to limit this broad approach has become more visible. The Federal Constitutional Court has emphasized the exceptional character of searches without judicial authorization and has required, in each case, information documenting the need to act immediately as well as the moment when the information reached the police and the efforts made to contact a judge ${ }^{62}$. On other occasions the Court has stressed the need to institute judicial emergency services to facilitate contact between the police officers needing to conduct a search and the judge of the investigation ${ }^{63}$.

Searches that take place in exigent circumstances without a judicial search warrant must be subsequently confirmed by the court ${ }^{64}$. Every person that such a search concerns can request subsequent judicial review of its legitimacy ( $\$ 98$ (2) CCP second sentence) and must be informed of the right to do so ( $\$ 98$ (2) CCP fifth sentence). In some

61 WEIGEND, Thomas. Germany, op. cit., p. 286 footnote 214.

62103 BVerfGE 142 (2000).

63 SIEGISMUND, Eberhard. The Public Prosecution Office in Germany: Legal Status, Function and Organization. Effective Administration of the Police and the Prosecution in Criminal Justice. The 120th International Senior Seminar, 2003. Available at: <https://www.unafei.or.jp/publications/pdf/RS_No60/ No60_10VE_Siegismund2.pdf>. Access on: 3 September 2020, p. 62.

64 TRENDAFILOVA, Ekaterina; RÓTH, Werner, op. cit., p. 233. 
cases, e.g. when neither a person concerned nor an adult was present during a search that resulted in the seizure of things, the request for judicial confirmation of such a search must be submitted to court within three days by the official conducting a search without a warrant ( $\$ 98$ (2) CCP first sentence). Additionally, those affected by the warrantless search may file an interlocutory appeal with a judge questioning the necessity and lawfulness of the search ${ }^{65}$. The power to move for such a remedy comes from the same regulation as the interlocutory appeal in the case of a search upon a warrant (\$ 304 CCP-Germany). For many years German law did not provide for exclusion of evidence on such basis ${ }^{66}$.

\section{COMPARISONS AND OBSERVATIONS}

\section{States' regulations compared}

The question of who shall be responsible to limit the arbitrariness of the government in cases involving searches of people, objects, and places remains crucial to providing sufficient protection of the rights of individuals. It is unquestionable that between the police officer wanting to conduct the search and the individual that such a search will be targeted at shall stand a decision maker in a capacity of a gatekeeper. This official shall be able to screen applications for search warrants and rule out the unjustified and unreasonable searches. But taking into account the number of warrantless searches that take place daily in all countries, even more striking remains the question of control over warrantless searches and the authority capable of exercising the control. The comparative research gives a full range of possible choices to that matter.

On the constitutional level it remains unclear between the analyzed countries what kind of official shall be considered as the authority responsible to issue search warrants. Neither the US nor Poland provides for constitutional regulation regarding officials authorized to order a

65 Ibidem., p. 233.

66 BRADLEY, Craig. The Exclusionary Rule in Germany. Harvard Law Review, n. 96, 1983, p. 1032. 
search in typical situations, leaving it for interpretation on the judicial (US) or normative (Poland) levels. On the other hand, in Germany the constitution clearly states that it should be a judge (Richter) that remains the only authority to issue search warrants. But this refers solely to the search of premises, while personal inviolability seems not to be protected in a similar way, at least as provided in Article 2 (2) of the German Constitution only guaranteeing as much as these rights (inviolability and physical integrity) may be interfered only pursuant by law. In the case of Italy, the constitution is less specific, using a more general and undefined expression of "judicial authority" (l'autorità giudiciaria). However, this shall be understood as either judge or prosecutor due to the position that the prosecutor traditionally retains in Italy. The same rules are also applicable to the search of premises.

But the lack of constitutional provisions in the US pinning down the authority eligible to issue search warrants does not stop American courts from determining that the only official authorized to order a search is a judge (magistrate), as confirmed in Mapp v. Ohio ${ }^{67}$. Surprisingly, Germany, the system traditionally perceived as the most inquisitorial, remains closest to the American idea of who should retain the power to order a search. German law provides for judicial search orders as a strict rule. At the same time, in Poland issuing a search warrant during a criminal investigation remains solely the responsibility of the prosecutor. At that stage of the criminal process, even if there were enough time to apply to a judge for a search warrant, the judge is legally excluded from doing so. Finally, in Italy, due to the interpretation that accepts prosecutors as "judicial authority", the prosecutor retains full power to issue search warrants.

In analyzing the Italian case, it seems surprising that the competence to issue a search warrant was vested in prosecutorial hands. Under the old Italian Code of Criminal Procedure of 1930, the power to order and conduct searches was assigned to the investigating judge (giudice istruttore $)^{68}$, a famous inquisitorial figure abandoned in the majority

$67 \quad 367$ U.S. 643 (1961).

68 ILLUMINATI, Giulio. The Frustrated Turn..., op. cit., p. 567. 
of continental countries ${ }^{69}$ and in 1988 in Italy. Thus, the new code of 1988 replaced the investigating judge with a new authority, creating the preliminary investigation judge with the main task of protecting the rights of those under investigation ${ }^{70}$. This authority has the power, upon request of the prosecutor, to adopt measures restricting the personal freedom of the accused during the preliminary investigation (e.g. pretrial detention) or to restrict their privacy, e.g. by authorizing a wiretap on a telephone ${ }^{71}$. Notwithstanding the adopted interpretation of the "judicial authority" equating judge and prosecutor, which formally allows the latter to issue search warrants, it was possible to adopt another resolution in which the preliminary investigation judge instead of the prosecutor would, in addition to authorizing arrest and detention, also preauthorize search warrants. It is worth noting that in the case of Poland, the situation is quite similar, granting power to issue some coercive measures to a judge (e.g. arrest and wiretaps) and some others like a search warrant to a prosecutor. However, the difference is in the detail - in Poland the prosecutor is not equated with a judge.

In light of the above, both the US and Germany seem to provide a higher standard of protection for the individual than do Poland and Italy. This standard may even seem quite similar, since in both countries only a judge may preauthorize a search. But one has to acknowledge another step in providing protection of privacy in the cases of all three examined continental states. They offer a right to file a motion (revision, interlocutory appeal) to verify the lawfulness of a search even in cases where the search was preauthorized. This is seen as an immediate remedy for an individual who believes that their rights were infringed by the search.

The US does not provide for any immediate remedy with regard to verification of the lawfulness of a search conducted upon a warrant. This may only be done when a case reaches a trial stage or, to a different

69 Almost the sole exceptions that still use this figure are France and Belgium. Nevertheless, many scholars with common law roots believe that this is one of the typical elements of the Continental system.

70 GRANDE, Elisabetta. Italian Criminal Justice: Borrowing and Resistance. American Journal of Comparative Law, n. 48, 2000, p. 233.

71 FABRI, Marco. Criminal Procedure and Public Prosecution Reform in Italy: A Flash Back. International Journal for Court Administration, n. 10, 2008, p. 10. 
extent, when a person demands the return of property. In the cases of Poland and Germany this remedy is available to every person regardless of an effect of such search to allow subsequent evaluation of the lawfulness or necessity of such a search. Italy gives a similar right to move to judgment for verification of a search but only in cases where the search resulted in the seizure of things.

At this point it is worth bringing up the position of the European Court of Human Rights (ECtHR), which provides for a minimum standard for protection of the rights of an individual among European countries members of the Council of Europe ${ }^{72}$. It is true that when it comes to search the ECtHR focuses mainly on the conduct of such measure in "accordance with law"73, whether the interference furthers a legitimate aim, ${ }^{74}$ and if is "necessary in a democratic society" comes to establishing the organ authorized to issue search warrants, but this does not preclude the ECtHR from demanding independent judicial supervision over searches ${ }^{76}$. However, the Court noted in Smirnov v. Russia that the absence of a prior judicial warrant may be counterbalanced by the availability of a post-factum judicial review ${ }^{77}$. On the other occasion in Heino v. Finland the ECtHR sustained that position, confirming that either prior or post judicial scrutiny over the decision to search is acceptable as a proper standard of protection ${ }^{78}$. This would mean that the judicial control

72 In the case of a search this is primarily a right to privacy as protected by Article 8 (2) of the European Convention on Human Rights and Freedoms [ECHR].

73 Halford v. The United Kingdom, no. 20605/92, 25 June 1997.

74 Mozer v. The Republic of Moldova and Russia, no. 11138/10, 23 February 2016, $\S 194$ (the ECtHR established that it is the responsibility of the government to demonstrate that the interference pursued a legitimate aim).

75 See among others Buck v. Germany, no. 41604/98, 28 April 2005 and Ratushna v. Ukraine, no. 17318/06, 2 December 2010.

76 Sallinen and Others v. Finland, no. 50882/99, 27 September 2005, § 89.

77 Smirnov v. Russia, no. 71362/01, 7 June 2007, § 45.

78 Heino v. Finland, no. 56720/09, 15 February 2011, § 46 ("[E]ven if there could be said to be a general legal basis for the impugned measures in Finnish law, that law does not provide sufficient judicial safeguards either before the granting of a search warrant or after the search. The applicant was thus deprived of the minimum degree of protection to which she was entitled under the rule of law in a democratic society"). 
over search warrants issued by a non-judicial authority (a prosecutor in the cases of Italy and Poland) is acceptable ${ }^{79}$. But the ECtHR makes it clear that the mere fact of the availability of such a remedy will not in itself necessarily amount to a sufficient safeguard against abuse. Such remedy must be considered as effective and this is assessed in the light of the specific circumstances of every case ${ }^{80}$.

Accordingly, Germany seems to be in full compliance with the standard as presented above. There is not only a prior judicial authorization of a search but also a remedy available to affected individuals that gives a second chance for a judicial review of the conducted measure. This interlocutory appeal depends on the will of the affected individual to go to a judge for such a resolution. In the case of Poland the revision by the judicial authority of a measure preauthorized by a prosecutor is also triggered upon a request of the individual. This raises the question of whether such a revision is effective and safeguards against possible abuse if only the action of the individual makes the revision possible. This is particularly troublesome when one takes into consideration that there is a seven-day time limit for the filing of an interlocutory appeal. This is also an issue in the case of Germany, but the obligatory preauthorization of the search makes a significant difference here.

To that extent the most problematic is the case of Italy. Here the judicial post-factum revision of a search upon a warrant issued by the prosecutor is only available in cases where the search resulted in seizure. This lack of judicial scrutiny in no-seizure cases was criticized by the ECtHR in the recent case Brazzi v. Italy ${ }^{81}$. The case concerned Marco Brazzi, an Italian and German national whose Italian house was searched in 2010 upon a warrant issued by the prosecutor of Mantua in connection with the ongoing criminal investigation involving alleged tax evasion by Brazzi. The ECtHR noted that the prosecutorial decision to authorize a search lacked any prior judicial oversight, which would not be an issue if it was counterbalanced by a subsequent judicial review, after the act,

\footnotetext{
79 Note that this applies to the same extent to the judicial reviews of warrantless searches.

80 Geraschenko v. Ukraine, no. 20602/05, 7 November 2013, § 130.

81 Brazzi v. Italy, no. 57278/11, 27 September 2018.
} 
as to the lawfulness and necessity of the measure. In the discussed case this however did not take place ${ }^{82}$. Therefore, since there was neither prior judicial oversight nor any effective ex post facto review of the impugned investigative measure, the ECtHR found that Italian law did not provide sufficient safeguards against the risk of abuse of power by the authorities conducting the criminal investigation and ruled the violation of Article 8 of the ECHR ${ }^{83}$. This seems in line with the previous judgment delivered in Modestou v. Greece ${ }^{84}$, concerning the search of a Cypriot national living in Greece whose house was searched upon a prosecutorial order, also without a prior or retrospective judicial review.

In all four examined countries it is reported that regardless of the rule that calls for preauthorization of a search in the form of a warrant, warrantless searches have become the norm, moving searches upon a warrant to a box with one name: exception. Therefore, the police and other agencies frequently conduct warrantless searches under a similar regime if they can prove that exigent circumstances have occurred. What is understood by exigent circumstances may vary from country to country but generally it shall be understood as a necessity to act immediately due to the possibility of losing evidence combined with the lack of opportunity to move for preauthorization of such a search.

However, this is where the similarities end. It is surprising how differently countries deal with the outcome of such searches and whether they provide an immediate opportunity to verify them. While US does not provide for any post-factum authorization of warrantless searches either by the prosecutor or a judge, all three continental countries demand it, differing only along the line of what authority should do so. Italy and Poland consider the prosecutor eligible for the post-authorization as well,

82 In fact it was argued that at some point the judge for preliminary investigation did eventually review the case, confirming the discontinuation of the preliminary investigation (which according to Article 408 CCP-Italy is obligatory in each case when the prosecutor believes that the charge is groundless).

83 The ECtHR decided similarly in the case Modestou v. Greece, no. 51693/13, 16 March 2017, concerning a Cypriot national living in Greece whose house was searched upon a prosecutorial order also without either a prior or retrospective judicial review.

Modestou v. Greece, no. 51693/13, 16 March 2017. 
and Germany resorts in this case to the judge too. Most importantly, however, all immediate remedies that the law provides in cases of a search upon a warrant discussed above also apply in cases of warrantless searches. Therefore, in the cases of Germany, Italy, and Poland the warrantless search is not only subsequently confirmed but is also subjected to judicial scrutiny upon the request of the individual whose rights were allegedly infringed, although in the case of Italy only when the search resulted with the seizure.

\section{NON-ELIGIBILITY OF PROSECUTOR TO AUTHORIZE SEARCHES}

The presented diversity of choices brings an obvious question of whether it is acceptable that the prosecutor may authorize searches conducted both with and without a warrant. This in fact should be rephrased to whether there are some circumstances under which the prosecutor could be considered as an authority allowed to authorize searches without prior or subsequent judicial scrutiny.

The US case law seems to have clear and convincing arguments to that matter. The good hand of US case law relating to search focuses on features of an official that would be allowed to make a decision to search, connecting it with a notion of "neutral and detached magistrate". This requirement was set 70 years ago when the Supreme Court stated that " $[\mathrm{t}]$ he point of the Fourth Amendment which often is not grasped by zealous officers is not that it denies law enforcement the support of the usual inferences reasonable men draw from evidence. Its protection consists in requiring that those inferences be drawn by a neutral and detached magistrate instead of being judged by the officer engaged in the often competitive enterprise of ferreting out crime." 85 The Supreme Court took some effort to explain it further. Interestingly, the "neutral and detached magistrate" does not necessarily have to be a lawyer. What is required from the issuing authority is neutrality and detachment from the case as well as capability to determine the existence of probable cause for the requested search ${ }^{86}$. On the other occasion the US Supreme

\footnotetext{
85 Johnson v. United States, 333 U.S. 10 (1948), para. 13-14.

86 Shadwick v. City of Tampa 407 U.S. 345 (1972), 350.
} 
Court sustained the position that the relation of the decision maker with the government is crucial in the evaluation of his eligibility to order an intrusion into privacy. It was observed that prosecutors associated with the executive have a duty and responsibility to enforce the laws, investigate, and prosecute and therefore, "should not be the sole judges of when to utilize constitutionally sensitive means in pursuing their tasks" since "unreviewed executive discretion may yield too readily to pressures to obtain incriminating evidence and overlook potential invasions of privacy $[\ldots]$ "..

From the case law presented above one can get the impression that perhaps what makes the prosecutor incapable of making such decisions like intrusion into privacy is his relation with the executive. Indeed, in the American system it raises almost no question that the prosecutor is seen as a part of the executive branch ${ }^{88}$. In the view of the US Supreme Court, "the Executive Branch has exclusive authority and absolute discretion to decide whether to prosecute a case" 89 . Therefore, in a system that makes a prosecutor a part of the executive branch an impartial referee seems necessary to resolve whether an intrusion in such rights of an individual as privacy is justified. This would mean that in countries where the prosecution service is associated with the judiciary the problem should disappear. But this is not the case.

In Germany the prosecutor is seen as a neutral, objective official who holds a quasi-judicial role in fact-finding, whose duty during a criminal investigation is to examine the facts regardless of whether or not they support the initial suspicion ${ }^{90}$. The prosecutor is obliged to investigate not only incriminating evidence but to look for evidence that might be of an exculpatory nature as well (Article 160 (2) CCP-Germany). Therefore, prosecutors are seen as "guardians of the law" (Wächter der Gesetzes)

87 United States v. United States District Court, 407 U.S. 297 (1972), para. 317.

88 GRAMCKOW, Heike. Prosecutor Organization and Operations in the United States. En: Promoting Prosecutorial Accountability, Independence and Effectiveness. Sofia: Open Society Institute Sofia, 2008, p. 391; NEUBAUER, David W.; FRADELLA, Henry F. America's Courts and the Criminal Justice System. Boston: Cengage, 2017, p. 192.

United Sates v. Nixon 418 US. 683, 693 (1974).

WEIGEND, Thomas. Germany, op. cit,, p. 266. 
with a task to support public order and legality ${ }^{91}$. The organization of the prosecution service, as well as selection and training, mirrors the system prescribed for judges and the courts of law ${ }^{92}$. These features mark the German prosecution service, at least on a normative level, as having strong regulations towards independence and impartiality. And yet the prosecutors in Germany are not considered as fully independent of the executive. The organization of the prosecution service with the Minister of Justice on top both at the federal and state level ( $\$ 147 \mathrm{COA}^{93}$ ) gives a clear impression of dependence on the executive ${ }^{94}$. Moreover, the prosecutors are obliged to carry out the orders of their superiors ( $\$ 146 \mathrm{COA}$ ), which may relate both to types of cases in general as well as to any individual case. It is also permissible that at any time in the course of proceedings a case can be taken out of the hands of an individual prosecutor and reassigned to another ( $\$ 145 \mathrm{COA})$. This all led the German Federal Constitutional Court to the conclusion that prosecution is a part of the executive ${ }^{95}$. The view of the majority would comply with this position, yet there are some who believe the opposite and some who would like to see prosecution as occupying an intermediate position between executive and judiciary ${ }^{96}$. And as a result, the German prosecutor is not seen as neutral enough to be able to make the decision to interfere with someone's privacy in the form of ordering a search in a typical situation.

91 TRENDAFILOVA, Ekaterina; RÓTH, Werner, op. cit., p. 213.

92 GILLIÉRON, Gwladys. Public Prosecutors in the United States and Europe. Cham: Springer, 2014, p. 264.

93 Court Organization Act (COA), Gerichtsverfassungsgesetz (GVG) of 9 May 1975.

94 WEIGEND, Thomas. The Prosecution Service in the German Administration of Criminal Justice. En: TAK, Peter J.P. (ed.). Tasks and Powers of the Prosecution Services in the EU Member States. Nijmegen: Wolf Legal Publishers, 2004, p. 212.

BVerfGE 32, 216 and BVerfGE 103, 142, 156.

See discussion on that issue showing different perspectives by TRENDAFILOVA, Ekaterina; RÓTH, Werner, op. cit., p. 236. See also SIEGISMUND, Eberhard, op. cit., p. 64; ELSNER, Beatrix; PETERS, Julia. The Prosecution Service Function within the German Criminal Justice System. En: JEHLE, Jörg-Martin; WADE, Marianne (eds.). Coping with Overloaded Criminal Justice Systems. The Rise of Prosecutorial Power Across Europe. Springer, Heidelberg: Springer, 2010, p. 208. 
In Poland in the past it was assumed that the prosecution service is a part of the judiciary ${ }^{97}$. The connection with the judicial power was justified through the similar organizational structure of courts and the prosecution service, the joint system of education and training for judges and prosecutors, and the same salary as well as promotion structure in both groups. But the recent changes of law resulting from the Prosecution Service Act of $2016^{98}$ aimed at the full subordination of the prosecution service to the Attorney General - the office held by the Minister of Justice - have changed the situation. Since the Attorney General gained the power to give instructions to any prosecutor regarding conducted investigations or prosecutions, including orders on what the person shall be charged with and with what kind of decision the individual case must be ended ${ }^{99}$, the Polish prosecution service cannot be presumed as anything other than fully subordinated to the executive ${ }^{100}$.

Perhaps the strongest position to that extent is held by the prosecutor in Italy. Italian prosecutors retain the judicial or at least quasi-judicial function ${ }^{101}$. This is a result of changes made to the Italian Constitution in 1948 that guaranteed the prosecutors the same level of independence as judges, positioning both groups within the judicial system (magitratura $)^{102}$. Therefore, prosecutors are understood as independent of any other powers and bound by law to only act in compliance with the strongly pronounced principle of mandatory prosecution, i.e. the legality

97 ZIĘBA-ZAŁUCKA, Hanna. Prokuratura w nowej ustawie z 2016 roku. Eksperyment z podległością władzy wykonawczej. Przegląd Prawa Konstytucyjnego, n. 33, 2016, p. 117 and sources cited in footnote 18.

98 Ustawa Prawo o prokuraturze [Prosecution Service Act] of 28 January 2016, Dz.U. 2016, poz. 177 (hereinafter: PSA 2016).

99 Article 8 PSA 2016.

${ }^{100}$ European Commission for Democracy Through Law (Venice Commission), Opinion on the Act on the Public Prosecutor's Office as Amended, No. 892/2017, Strasbourg, 11 December 2017, https://www.venice.coe.int/webforms/documents/default.aspx?pdffile=CDL-AD(2017)028-e, para. 115.

${ }^{101}$ CAIANIELLO, Michele. The Italian Public Prosecutor: An Inquisitorial Figure in Adversarial Proceedings. In: LUNA, Erik; WADE, Marianne (eds.). The Prosecutor in Transnational Perspective. Oxford: Oxford University Press, 2012, p. 250.

102 See Articles 104-106 of the Italian Constitution. 
principle (Article 112 of the Italian Constitution) ${ }^{103}$. Their role is to prosecute cases, but they also maintain full control over the investigation ${ }^{104}$. The prosecutors are also seen by the Italian Constitutional Court as "mere prosecutors, but also an organ of justice that is obliged to search for all elements of evidence that are relevant for the correct verdict, including any elements in favor of the accused" ${ }^{105}$. This all leads to the Italian prosecution service being positioned closer to the judicial and not the executive power ${ }^{106}$. And if it was indeed true that the Italian prosecutor is as independent and impartial as a judge it would be understandable that the prosecutor may have similar authority, including a power to impose during criminal investigation such coercive measures as search warrants.

But the independence of the prosecution service as prescribed on the normative level does not remain uncontested ${ }^{107}$. Even Italian law seems to have some doubts when it comes to the full equality of judges and prosecutors. While the prosecutor is allowed to impose some coercive measures during criminal investigation, e.g. the search, seizure, summoning, and questioning of witnesses, other remain outside of his competencies - detention (Article 275 CCP-Italy) and the interception of communication (Article 267 CCP-Italy) ${ }^{108}$. This shows some lack of trust in prosecutors when making crucial decisions during a criminal investigation. Moreover, some scholars aptly argue that a system in which judges are structurally more proximate to the prosecutor than to the defendant can cause natural tendency to rule in favor of the prosecution, which leads

${ }^{103}$ ILLUMINATI, Giulio. The Role of the Public Prosecutor..., op. cit., p. 313.

${ }^{104}$ RUGGIERI, Francesca; MARCOLINI, Stefano. Italy. En: LIGETI, Katalin (ed.). Toward a Prosecutor of the European Union, Volume 1: A Comparative Analysis. London: Hart Publishing, 2013, p. 369.

${ }^{105}$ Corte Costituzionale [Italian Constitutional Court], 15 February 1991, no. 88.

106 MONTANA, Ricardo. Adversarialism in Italy: Using the Concept of Legal Culture to Understand Resistance to Legal Modifications and Its Consequences. European Journal of Crime, Criminal Law and Criminal Justice, n. 20, 2012, p. 109.

${ }^{107}$ SCACCIANOCE, Caterina. The principle of mandatory prosecution and the independence of public prosecutors in the Italian Criminal Justice System. ReAIDP/e-RIAPL A-01, 2010, p. 6.

108 See more on the scope of other coercive measures than search in Italian criminal proceedings in RUGGIERI, Francesca; MARCOLINI, Stefano, op. cit., pp. 370-389. 
to a clear violation of the equality-of-arms principle ${ }^{109}$. There are also some valid doubts whether the influence of the Ministry of Justice on the prosecution service exists ${ }^{110}$.

Taking the presented arguments under consideration, one can wonder if the only factor that excludes the prosecutor from being competent to authorize searches is the subordination to the Ministry of Justice and the proximity that the prosecutor has towards the executive power. It seems that the relationship that the prosecutor builds with the criminal justice agencies, mainly the police, and his level of engagement in the conduct of criminal investigation remains relevant.

This problem was addressed on several occasions by the US Supreme Court. For instance, in Coolidge v. New Hampshire ${ }^{111}$ it was confirmed that the Attorney General does not have the level of detachment and neutrality that is demanded from an authority issuing search warrants. The fact that the Attorney General of New Hampshire was formally and unquestionably authorized, under then-existing law, to issue search warrants as a justice of peace, became an important issue in this case. Even though he would regularly issue search warrants, such activity raised some valid questions. The Supreme Court pointed out that in this case the Attorney General took charge of all police activities relating to the murder at stake and took a role of the chief prosecutor in the trial following the investigation. This made it ultimately obvious that he could not be seen as sufficiently neutral. The relation that the Attorney General had with a case and with officers conducting the investigation made him too involved to be allowed to make such decisions as ordering a search. According to the US Supreme Court, participation in the search by the person that issued the search warrant is not compatible with a neutral and detached magistrate ${ }^{112}$.

109 DI FEDERICO, Giuseppe. Prosecutorial Independence and the Democratic Requirement of Accountability in Italy: Analysis of a Deviant Case in a Comparative Perspective. British Journal of Criminology, n. 38, 1998, pp. 381-382.

${ }^{110}$ CAIANIELLO, Michele. The Italian Public Prosecutor..., op. cit., p. 256.

111 Coolidge v. New Hampshire, 403 U.S. 443 (1971).

${ }^{112}$ Lo-Ji Sales, Inc. v. New York, 442 U.S. 319 (1979), para. 327 ("[the magistrate] allowed himself to become a member, if not the leader, of the search party which was essentially a police operation. Once in the store, he conducted a 
The decision to search should be made in a normal situation by an authority not engaged in criminal investigations, since only in this way can a desired level of objectivity and independence in the evaluation of this measure be ensured. This remains true for the engagement of every single prosecutor in proceedings in a case where the decision to conduct a search is to be made. But it also relates to the position of the prosecution service in general where the prosecution service remains in a long-term relationship with the criminal justice agencies conducting criminal investigations. How can one independently evaluate the need to conduct a search if one is pushed to grant authority by police officers with whom one works closely every day?

The prosecutor cannot guarantee such standards while he or she remains both organizationally and procedurally engaged in criminal investigation. This is a case for all continental countries. In Germany the control of the prosecutor of criminal investigations remains undisputed, allowing him to give orders to police officers while they conduct investigations (Article 161 (1) CCP-Germany) ${ }^{113}$. Similarly, in Italy the prosecution service supervises criminal investigations, exercising control over the investigating officers by giving orders and directing the investigative process ${ }^{114}$. The close connection that the Italian prosecutors retain with police during the conduct of criminal investigations is also clearly seen by the obligation of the police to immediately pass information (Article 347 (1) CCP-Italy) on the possible committing of a crime (notitia criminis) to the prosecutor as well as subordinating police to him (Article 327 CCP-Italy). That immediately gives him full control over police actions ${ }^{115}$. This is also true for Poland, where the prosecutor - typically

generalized search under authority of an invalid warrant; he was not acting as a judicial officer, but as an adjunct law enforcement officer"). Cf. Connally $v$. Georgia, 429 U.S. 245 (1977) (In this case the US Supreme Court held unconstitutional the statute that authorized payment of five dollars to each magistrate issuing a search warrant while no money was given to those denying warrants). See also similar arguments in cases involving payment received by judges upon conviction in Tumey v. Ohio, 273 U.S. 510 (1927).

113 GILLIÉRON, Gwladys, op. cit., p. 266.

${ }^{114}$ CAIANIELLO, Michele. The Italian Public Prosecutor..., op. cit., p. 251.

115 This is true regardless of the fact that the police are not forbidden from undertaking some investigative actions themselves, as provided in Article 348 CCP-Italy. 
known as "the master of proceedings" (dominus litis) - plays a key role during criminal investigations ${ }^{116}$. The Polish prosecutor either conducts the criminal investigation or supervises it in cases where the police are allowed by law to conduct it (Article 298 (1) CCP-Poland). Therefore, the scope of powers of the prosecutor especially with regard to control over police investigative actions is broad, including taking part in the investigation as well as giving orders to the police officers (Article 326 (3) CCP-Poland).

Such normatively prescribed prosecutorial control over criminal investigation might however be differently employed in practice. In particular in less serious cases, the prosecutorial engagement of the prosecutor might be visibly reduced or even somewhat illusionary until final decisions on how to end a case are made. But this does not undermine the strong relationship that bounds the prosecution service and the police built to achieve the aim of obtaining enough evidence to prove the guilt of the defendant. They work closely on a daily basis, even if this cooperation is stronger in the case of more serious crimes. They discuss, consult, and investigate together. Therefore, this long-term bond makes it hard or even impossible to make decisions independently enough to aspire to the high standard demanded by the imposition of such measures as search.

The close relationship of the prosecutor with the law enforcement authorities and his involvement in the course of procedural activities undertaken during the criminal process makes his perspective too narrow, or even tunneled, which makes it impossible to objectively assess the need for searches. It seems that vesting in prosecutorial hands the power to decide on such a measure results more from the pragmatic reasons aimed at the quick and efficient conduct of criminal investigations without resorting to judicial authority.

\section{Conclusions}

As aptly summed up by the US Supreme Court in Brinegar $v$ U.S., " $[\mathrm{u}]$ ncontrolled search and seizure are the first and most effective

${ }^{116}$ NOWAK, Celina; STEINBORN, Sławomir, op. cit., p. 499. 
weapons in the arsenal of every arbitrary government"117. It remains true for every legal system, regardless of whether inquisitorial or adversarial. It is clear that restrictions imposed on the right to privacy should be applied in a way that protects the individual to the highest possible extent. Notwithstanding the need to conduct effective investigations to fight crime efficiently, coercive measures shall only be performed when they are necessary and only when certain grounds are met.

It is broadly accepted that officers engaged in the daily work of law enforcement agencies are incapable of evaluating properly the need to conduct searches. Therefore, searches must be subjected to the scrutiny of an independent organ that would be entitled to authorize these measures prior to their execution and assess them when they have already taken place. As the research shows, the prosecutor cannot be regarded as such an authority. The assumed proximity to the executive power excludes the prosecutor from being granted with the same level of impartiality and independence as the judge, even if the legal provisions in some countries tend to prove the opposite. And even more important is the relationship that the prosecutor builds with the police and other law enforcement agencies conducting criminal investigations. The close cooperation built upon the cases investigated and prosecuted together with criminal justice agencies raises the likelihood that the prosecutor will become prejudiced towards the investigative actions planned and conducted by these agencies. Therefore, it should be considered that the prosecutor does not have the necessary amount of objectivity required in such cases.

This altogether makes the prosecutor incompetent to authorize searches, regardless of whether it is done prior to the search or postfactum. Such power should be granted solely to the judge as an authority providing the adequate protection of the rights of the person to privacy. The judicial oversight of searches does not guarantee lawful and reasonable behavior in all cases, but it undoubtedly increases the protection of an individual's rights.

117 Brinegar v US 338 US 160 (1949) 180. 


\section{References}

AMODIO, Ennio; SELVAGGI, Eugenio. An Accusatorial System in a Civil Law Country: The 1988 Italian Code of Criminal Procedure. Temple Law Review, n. 62, 1989.

BRADLEY, Craig. The Exclusionary Rule in Germany. Harvard Law Review, n. 96, 1983.

CAIANIELLO, Michele. The Italian Public Prosecutor: An Inquisitorial Figure in Adversarial Proceedings. In: LUNA, Erik; WADE, Marianne (eds.). The Prosecutor in Transnational Perspective. Oxford: Oxford University Press, 2012.

CAIANIELLO, Michele. Increasing Discretionary Prosecutor's Powers: The Pivotal Role of the Italian Prosecutor in the Pretrial Investigation Phase. Oxford: Oxford Handbooks Online, 2016. http://doi.org/10.1093/oxfordhb/9780199935383.013.122

COLB, Sherry F. Probabilities in Probable Cause and Beyond: Statistical Versus Concrete Harms. Law and Contemporary Problems, n. 73, 2010.

DI AMATO, Astolfo. Criminal Law in Italy. Alphen aan den Rijn: Kluwer Law International, 2013.

DI FEDERICO, Giuseppe. Prosecutorial Independence and the Democratic Requirement of Accountability in Italy: Analysis of a Deviant Case in a Comparative Perspective. British Journal of Criminology, n. 38, 1998.

DRESSLER, Joshua; THOMAS III, George. Criminal Procedure. Principles, Policies and Perspectives. St Paul: West Academic, 2017.

ELSNER, Beatrix; PETERS, Julia. The Prosecution Service Function within the German Criminal Justice System. In: JEHLE, Jörg-Martin; WADE, Marianne (eds.). Coping with Overloaded Criminal Justice Systems. The Rise of Prosecutorial Power Across Europe. Heidelberg: Springer, 2010.

FABRI, Marco. Criminal Procedure and Public Prosecution Reform in Italy: A Flash Back. International Journal for Court Administration, n.10, 2008.

FRASE, Richard; WEIGEND, Thomas. German Criminal Justice as a Guide to American Law Reform. Boston College International and Comparative Law Review, n. 18, 1995.

GILLIÉRON, Gwladys. Public Prosecutors in the United States and Europe. Cham: Springer, 2014.

GRAMCKOW, Heike. Prosecutor Organization and Operations in the United States. In: Promoting Prosecutorial Accountability, Independence and Effectiveness. Sofia: Open Society Institute Sofia, 2008. 
GRANDE, Elisabetta. Italian Criminal Justice: Borrowing and Resistance. American Journal of Comparative Law, n. 48, 2000.

GRAY, David. Fourth Amendment Remedies as Rights: The Warrant Requirement. Boston University Law Review, n. 96, 2016.

GROCHOWSKI, Jacek. Przeszukanie w procesie karnym jako instytucja wyznaczająca granice konstytucyjnych praw osobistych. Problemy Prawa Karnego, n. 17, 1991.

ILLUMINATI, Giulio. The Role of the Public Prosecutor in the Italian System. In: TAK, Peter J.P. (ed.). Tasks and Powers of the Prosecution Services in the EU Member States. Nijmegen: Wolf Legal Publishers, 2004.

ILLUMINATI, Giulio. The Frustrated Turn to Adversarial Procedure in Italy (Italian Criminal Procedure Code of 1988). Washington University Global Studies Law Review, n. 4, 2005.

KUHNE, Heinz-Heinrich. Germany. In: VAN DEN WYNGAERT, Christine (ed.). Criminal Procedure Systems in the European Community. London: Butterworths, 1993.

KOPER, Radosław. Przeszukanie w wypadkach niecierpiących zwłoki. Prokuratura i Prawo, n. 11-12, 2014.

KREMENS, Karolina. The limits of interference with the right to privacy and property in criminal proceedings. In: SKORUPKA, Jerzy (ed.). The model of acceptable interference with the rights and freedoms of an individual in criminal process. Warszawa: Wolters Kluwer, 2019.

LASAGNI, Giulia. Tackling phone searches in Italy and the United States: Proposals for a technological rethinking of procedural rights and freedoms. New Journal of European Criminal Law, n. 9, 2018.

MONTANA, Ricardo. Adversarialism in Italy: Using the Concept of Legal Culture to Understand Resistance to Legal Modifications and Its Consequences. European Journal of Crime, Criminal Law and Criminal Justice, n. 20, 2012.

NEUBAUER, David W.; FRADELLA, Henry F. America's Courts and the Criminal Justice System. Boston: Cengage, 2017.

NOWAK, Celina; STEINBORN, Sławomir. Poland. En: LIGETI, Katalin (eds.). Toward a Prosecutor of the European Union, Volume 1: A Comparative Analysis. London: Hart Publishing, 2013.

PANZAVOLTA, Michele. Reforms and Counter-Reforms in the Italian Struggle for an Accusatorial Criminal Law System. North Carolina Journal of International Law \& Commercial Regulation, n. 30, 2004. 
PERRODET, Antoinette. The Italian System. In: DELMAS-MARTY, Mireille; SPENCER, John R (eds.). European Criminal Procedures. Cambridge: Cambridge University Press, 2002.

RUGGIERI, Francesca; MARCOLINI, Stefano. Italy. In: LIGETI, Katalin (ed.). Toward a Prosecutor of the European Union, Volume 1: A Comparative Analysis. London: Hart Publishing, 2013.

SAKOWICZ, Andrzej. Poszanowanie życia prywatnego w postępowaniu karnym. Jurysta, n. 6, 2000.

SCACCIANOCE, Caterina. The principle of mandatory prosecution and the independence of public prosecutors in the Italian Criminal Justice System. ReAIDP/e-RIAPL A-01, 2010.

SCHEB, John M; SCHEB, John M II. Criminal Procedure. Belmont: Wadsworth, 1999.

SIEGISMUND, Eberhard. The Public Prosecution Office in Germany: Legal Status, Function and Organization. Effective Administration of the Police and the Prosecution in Criminal Justice. The 120th International Senior Seminar, 2003. Available at: <https://www.unafei.or.jp/publications/pdf/RS_No60/No60_10VE_ Siegismund2.pdf>. Access on: 3 September 2020.

SKORUPKA, Jerzy. Konstytucyjne i konwencyjne granice przeszukania w postępowaniu karnym (cz. I). Palestra, v. 9-10, 2007.

SKORUPKA, Jerzy. Konstytucyjne i konwencyjne granice przeszukania w postępowaniu karnym (cz. II). Palestra, n. 11-12, 2007.

SKORUPKA, Jerzy. Komentarz do art. 220 k.p.k. En: SKORUPKA, Jerzy (ed.), Kodeks postępowania karnego. Komentarz. Warszawa: CH Beck, 2018.

STEINBORN, Sławomir. Problem organu uprawnionego do stosowania przeszukania w toku procesu karnego w świetle unormowań konstytucyjnych i prawnomiędzynarodowych. Gdańskie Studia Prawnicze, n. 19, 2008.

TRENDAFILOVA, Ekaterina; RÓTH, Werner. Report on the Public Prosecution Service in Germany. In: Promoting Prosecutorial Accountability, Independence and Effectiveness. Sofia: Open Society Institute Sofia, 2008.

WEIGEND, Thomas. The Prosecution Service in the German Administration of Criminal Justice. In: TAK, Peter J.P. (ed.). Tasks and Powers of the Prosecution Services in the EU Member States. Nijmegen: Wolf Legal Publishers, 2004. 
WEIGEND, Thomas; SALDITT, Franz. The Investigative Stage of the Criminal Process in Germany. In: CAPE, Ed; HODGSON, Jacqueline; PRAKKEN, Ties; SPRONKEN, Taru (eds.). Suspects in Europe. Antwerpen: Intersentia, 2007.

WEIGEND, Thomas. Germany. In: LIGETI, Katalin (ed.). Toward a Prosecutor of the European Union, Volume 1: A Comparative Analysis. London: Hart Publishing, 2013.

ZIĘBA-ZAŁUCKA, Hanna. Prokuratura w nowej ustawie z 2016 roku. Eksperyment z podległością władzy wykonawczej. Przegląd Prawa Konstytucyjnego, n. 33, 2016.

ZWEIGERT, Konrad, KÖTZ, Hein. Introduction to Comparative Law. Oxford: Clarendon Press, 2011.

\section{Additional information and author's declarations (scientific integrity)}

Acknowledgement: This work is a result of the research project financed by the Polish National Science Center 2018/30/E/ HS5/00338. The earlier version of this article has been presented during the $8^{\text {th }}$ Annual Conference of the Younger Comparativists Conference of the ASCL held at the McGill Law School on May 10, 2019. I am grateful to all participants for their helpful comments.

Conflict of interest declaration: the author confirms that there are no conflicts of interest in conducting this research and writing this article.

Declaration of authorship: all and only researchers who comply the authorship requirements of this article are listed as authors; all coauthors are fully responsible for this work in its entirety.

Declaration of originality: the author assures that the text here published has not been previously published in any other resource and that future republication will only take place with the express indication of the reference of this original publication; she also attests that there is no third-party plagiarism or self-plagiarism. 
Dados do processo editorial

(http://www.ibraspp.com.br/revista/index.php/RBDPP/about/editorialPolicies)

- Recebido em: 07/07/2020

Equipe editorial envolvida

- Controle preliminar e verificação de plágio: 07/07/2020

- Editor-chefe: 1 (VGV)

- Avaliação 1: 20/07/2020

- Revisores: 3

- Avaliação 2: 26/07/2020

- Avaliação 3: 11/08/2020

- Decisão editorial preliminar: 15/08/2020

- Retorno rodada de correções: 04/09/2020

- Decisão editorial final: 08/09/2020

\section{COMO CITAR ESTE ARTIGO:}

KREMENS, Karolina. The authority to order search in a comparative perspective: a call for judicial oversight. Revista Brasileira de Direito Processual Penal, Porto Alegre, vol. 6, n. 3, p. 1585-1626, set./dez. 2020. https://doi.org/10.22197/rbdpp.v6i3.412

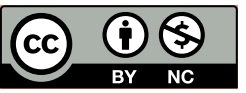

Esta obra está licenciada com uma Licença Creative Commons Atribuição-NãoComercial 4.0 Internacional. 